\title{
Budgeting for the long run
}

\author{
As the United States Congress confronts budgeting challenges, whether federal funding of scientific \\ research is perceived as an investment or a discretionary expense will have long-term consequences.
}

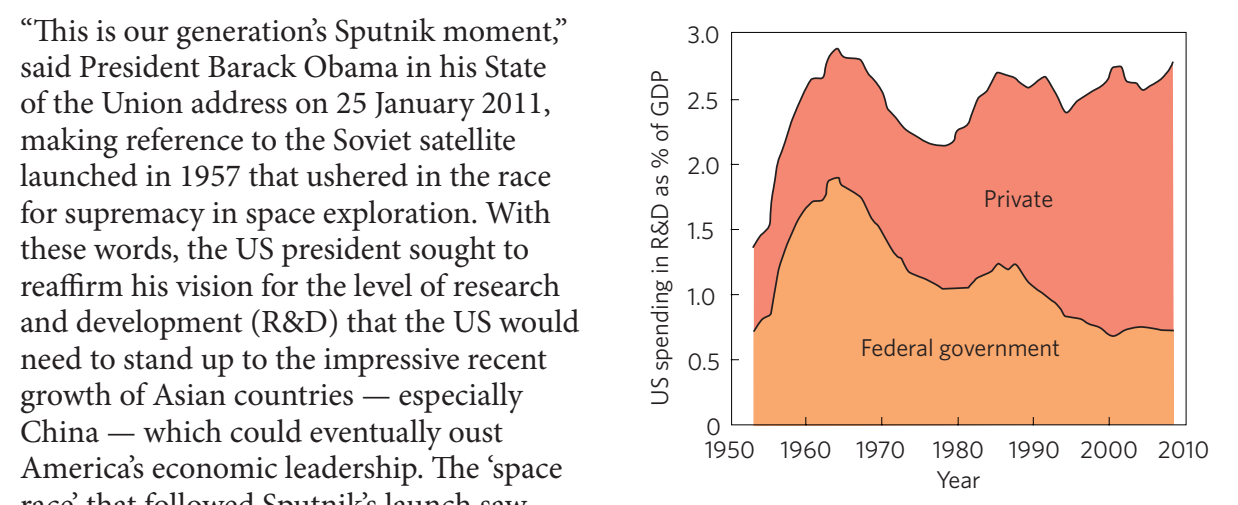

race' that followed Sputnik's launch saw unprecedented increases in spending on research and education, and a wave of scientific advances and technological innovation that created new businesses and millions of jobs.

The conviction that funding basic research to foster innovation is a key to revitalizing the burdened US economy in the long term is stamped on 'The President's Plan for Science and Innovation', which proposed to double the budgets of three government agencies - the National Science Foundation (NSF), the Department of Energy's Office of Science (DOE SC) and the National Institute of Standards and Technology (NIST) - from their 2006 levels by 2017. In accordance with this plan, President Obama's 2012 budget request to Congress proposes to increase funding by $14 \%$ to $\$ 7.8$ billion for the NSF, by $11 \%$ to $\$ 5.4$ billion for the DOE SC and by $47 \%$ to $\$ 1.1$ billion for the NIST, as compared with the just-enacted 2011 budget $^{2}$.

Expectedly, the views of the Obama administration on funding basic science are not shared by the Republican-controlled US Congress. The budget for federal year 2011 agreed by congressional leaders after hours on 9 April, thus narrowly avoiding a US government shutdown, reduced funding for the three agencies by 7.6\% (NSF), $4.8 \%$ (DOE SC) and 18\% (NIST) with respect to the President's proposed budget for the same year ${ }^{2}$. As a result, for federal year 2011 Congress effectively approved budget cuts amounting to a fraction of a per cent decrease on 2010 levels for the NSF and the DOE SC, and a $12.4 \%$ decrease for NIST.

The minor budget cuts for the NSF and the DOE SC have been a relief to the
Figure 1 | In the US, the decline in research and development spending by the federal government as percentage of GDP has been offset by the private sector. Source: National Science Foundation; Bureau of Economic Analysis.

scientific community in general, and to materials scientists in particular, as most research grants in materials research are funded by these two agencies. The budget of the National Institutes of Health (NIH), a federal agency which contributes to funding research on biomedical materials, has been cut barely $1 \%$ in 2011 , and the administration's proposed increase for the coming year is $3.7 \%$.

However, the fact that funding for science was eventually protected from large cuts at the negotiating table does not suggest a rosier future for the US scientific enterprise. Bipartisan efforts, such as the doubling of the NIH budget to roughly $\$ 30$ billion in 2004 from $\$ 15$ billion in 1998, are needed to bolster scientific breakthroughs and technological innovation in non-biomedical fields. Excluding the $\mathrm{NIH}$, funding for non-defence R\&D has remained flat for the past two decades at less than $\$ 30$ billion a year ${ }^{3}$, while inflation in the same period has surpassed $70 \%$.

(Adjusting for inflation, $\$ 30$ billion in 1990 is equivalent to approximately 50 billion of today's dollars.)

As a matter of fact, federal funding for R\&D spending as a percentage of gross domestic product (GDP) has been decreasing almost continuously since the peak in the mid 1960s - the years of the 'space race' (Fig. 1). Conversely, private spending in R\&D since the early 1980s has counterbalanced the trend, and total $\mathrm{R} \& \mathrm{D}$ spending as a percentage of GDP has yo-yoed between $2.2 \%$ and $2.8 \%$ for the past 25 years - certainly above the $1.7 \%$ corresponding to the European Union and the $2.3 \%$ for the 34 members of the Organisation for Economic Co-operation and Development (numbers corresponding to 2008$)^{4}$. China more than doubled the R\&D expenditure over GDP from $0.6 \%$ in 1996 to $1.5 \%$ in 2007 , and this percentage is expected to keep rising ${ }^{4}$.

Yet the private sector largely invests in projects that are considered as likely to lead to profits, and hence cannot fully substitute for taxpayers' money in funding initiatives that are riskier or solely knowledge-driven. Indeed, the Internet, the laser, the Global Positioning System and magnetic resonance imaging largely stemmed from governmentfunded 'blue-sky' research.

If history is any indication, long-term economic growth will be fuelled by waves of technologies that may very well originate from ideas that are driven by curiosity rather than profit. However, this conviction does not seem to be shared by Paul Ryan, the Republican chairman of the House Budget Committee, whose budget proposal signals the view that scientific research should join austerity measures and undertake severe cuts. An analogy of this view would be the case of parents saving money on their children's education to balance the family budget. The same way most parents perceive education as an investment rather than a discretionary expense, we as responsible citizens ought to recognize that funding good research proposals is a short-term expense that pays off in the long run. If only long-term difficult-to-quantify investments were simple to grasp; the story goes that in 1957 the Soviets made it easier.

\footnotetext{
References

1. http://www.whitehouse.gov/sites/default/files/doubling $\% 2011 \% 20$ final.pdf

2. http://news.sciencemag.org/scienceinsider/budget_2012

3. Intersociety Working Group AAAS Report XXXV: Research and Development FY 2011 (American Association for the Advancement of Science, 2010); available at http://www.aaas.org/ spp/rd/rdreport2011.

4. Organisation for Economic Co-operation and Development OECD Factbook 2008: Economic, Environmental and Social Statistics (OECD Publishing, 2008); available at http://www. sourceoecd.org/factbook.
} 